\title{
What are the Individual's Real Cares to Switch Personal Cloud Services?
}

\begin{tabular}{|c|c|}
\hline I . Introduction & 4.2 Construct operationalization \\
\hline П. Literature Review & 4.3 Data collection \\
\hline 2.1 Cloud Computing & V. Data analysis \\
\hline 2.2 Switching Research & 5.1 Validity \& Reliability analysis of research \\
\hline 2.3 Two-Factor Theory & model \\
\hline III. Research model and hypotheses & 5.2 Model fit analysis of research model \\
\hline 3.1 Switching enablers and switching & 5.3 Hypotheses test \\
\hline intention & VI. Implications \\
\hline 3.2 Switching inhibitors and switching & 6.1 Implications for academic researchers \\
\hline intention & 6.2 Implications for cloud service \\
\hline 3.3 Control variables and switching intention & practitioners \\
\hline 3.4 AHP Hierarchy Structure & VII. Conclusion \\
\hline 3.5 Factors and Strategies Evaluation & Reference \\
\hline IV. Research design & $<$ Abstract $>$ \\
\hline 4.1 Research model & \\
\hline
\end{tabular}

\section{Introduction}

In recent years, the development of cloud computing has a rapid growth. According to Gartner's prediction, the continuous increasing trend of cloud computing market would last, at least, until 2014. The global market revenues of cloud computing will exceed \$150 billion in 2014 and will exceed $\$ 180$ billion in 2015. While businesses have been deploying cloud technology for some time, it's only recently that personal cloud computing have emerged. Personal cloud

* Ph.D. Student, Graduate School of Dongguk University, luoweiyi1984@gmail.com

** Professor, School of Management, Dongguk University, Corresponding Author, chanlee@dongguk.ac.kr 
computing, as an emerging field of cloud services, has attracted enormous attention from both practitioners and academics.

Even there are lots of empirical studies in the field of cloud computing (Ratten, 2012; Gupta et al., 2013; Lian et al., 2014), but few of them gives an insight to the adoption or switching behavior of cloud computing in the individual level. Whether the factors, found as important drivers to impact on the adoption or switching behavior of cloud computing in the enterprise level, still play the important role in the individual level is still questionable. Therefore, it's meaningful for us to conduct a study to provide a more comprehensive understanding on the switching behavior of cloud computing in the individual level.

\section{Literature Review}

\subsection{Cloud Computing}

In computer networking, cloud computing is computing that involves a large number of computers connected through a communication network such as the Internet, similar to utility computing (Mariana et al. 2012). In science, cloud computing is a synonym for distributed computing over a network, and means the ability to run a program or application on many connected computers at the same time (Wikipedia). In application level, network-based services, which appear to be provided by real hardware and are, in fact, served up by virtual hardware simulated by software running on one or more real machines, are often called cloud computing (Wikipedia). Such virtual servers do not physically exist and can therefore be moved around and scaled up or down on the fly without affecting the end user, somewhat like a cloud becoming larger or smaller without being a physical object. In common usage, Rayport \& Heyward (2009) define cloud computing as a new way to deploy computing technology to give users the ability to access, work on, share, and store information via the Internet. Marketers have further popularized the phrase "in the cloud" to refer to software, platforms and infrastructure that are sold "as a service" (i.e. remotely through the Internet). Typically, the seller has actual energy-consuming servers which host products and services from a remote location, so end-users don't have to; they can simply log on to the network without installing anything. The major models of cloud computing services are known as software as a service (SaaS), platform as a service (PaaS), and infrastructure as a service (IaaS). Ambrose \& Chiravuri (2010) define that SaaS refers to the paradigm where software and other solutions are delivered to the end-users as a service using the Internet rather than as a product that can be installed on the user's computer. These cloud services may be offered in a public, private or hybrid network. Google, Amazon, Oracle, Salesforce, Zoho and Microsoft are some well-known cloud vendors. Cloud services 
generally refer to as SaaS, but the other terms of cloud services, such as PaaS or IaaS, has also been adopted by lots of vendors to differentiate the unique characteristics of their products. In fact, PaaS or IaaS usually be adopted to describe the cloud computing services in the enterprise level; and SaaS usually be adopted to describe the cloud computing services in the individual level. As the main purpose of this study is to understand the switching behavior of cloud computing in the individual level, SaaS is the only concern in this study.

As Google's Android has become the world's most popular mobile operating system, the Google Drive, which is usually pre-installed in the Android-based Smartphone, has also become one of the most popular cloud office services in the world. Google Drive is a file storage and synchronization service provided by Google, released on April 24, 2012. Cloud storage, file sharing and collaborative editing usually can be considered as the main functions of cloud office services (Mossberg, 2012). Google Drive is the home of Google Docs - an office suite of productivity application that offers collaborative editing on documents, spreadsheets, presentations, and more. According to Gartner's statistics report in 2012, in the global market, Microsoft office has occupied $90 \%$ market share in the field of PC office services while Google Drive has occupied 33\% market share in the field of cloud office services. And the global market share of Google Drive would rise up to $50 \%$ in 2013. Considering the high comparability between Microsoft office and Google Drive, we decide to adopt Microsoft office and Google drive to represent incumbent IT and cloud services in this study, respectively.

\subsection{Switching research}

In recent studies, although various theoretical models, such as the Theory of Planned Behavior (TPB; Ajzen \& Fishbein, 1980), the Technology Acceptance Model (TAM; Davis et al., 1989), and the Unified Theory of Acceptance and Use of Technology (UTAUT; Venkatesh et al., 2003) have addressed the switching behavior towards IT services, but few of them has been conducted to include enablers and barriers simultaneously in examining the switching behavior towards IT services (Kim et al., 2006; Liu et al., 2011). Not as initial adoption behavior or post-adoption behavior, inhibitors are also important antecedents of non-adoption behavior or switching behavior (Cenfetelli \& Schwarz, in press). In other words, in the context of non-adoption or switching behavior, the theories, which include both enablers and inhibitors, are more suitable and can provide a more comprehensive interpretation compared to the theories mentioned above. The double-barreled theories, such as Value-Based Adoption Model (VBAM; Kim et al., 2007), Two-Factor Theory (TFT; Herzberg, 1987), and Push-Pull-Mooring Model (PPMM; Bansalet et al., 2005) have been 
adopted and verified by lots of prior studies in the context of switching behavior (Hou et al., 2011; Park \& Ryoo, 2013; Hsu, 2014). Considering the main purpose of this study is to explore the direct effects of potential enablers and inhibitors on individual's switching intention, Two-Factor Theory will be adopted to develop the conceptual framework in this study.

\subsection{Two-Factor Theory}

Two-Factor Theory of IT usage, which is adapted from Herzberg's two-factor motivation (Herzberg et al., 1959), has emerged recently in IS research (Lee et al., 2009; Liu et al., 2011). After several decades, Two-Factor Theory has been applied to numerous other research context, such as positive VS negative emotions (Diener et al., 1995), interpersonal trust VS distrust (Lewicki et al., 1998).

Based on Two-Factor Theory, all the potential factors are characterized into two main constructs: enablers and inhibitors. In the context of switching behavior, switching enablers refer to the factors that motivate users to switch to a new product/service as well as the switching inhibitors refer to the factors that keep the users to continuance use an incumbent product/service. It's worth noting that each of these two constructs is not opposite to the other. In other words, enablers are not the polar opposites of inhibitors. For instance, the satisfaction with incumbent IT is one of the most important inhibitors to prevent users from switching to a new IT (Ye et al., 2008), but the absence of the satisfaction with incumbent IT does not necessarily increase user's switching intention to adopt a new IT. Moreover, an individual can hold the perceptions of both enablers and inhibitors simultaneously when he/she conduct the decision making process towards switching behavior. In this study, we will explore the potential enablers and inhibitors suggested by prior studies and test their direct influences on individual's switching intention in the context of could office services.

\section{Research model and hypotheses}

\subsection{Switching enablers and switching intention}

\section{Perceived omnipresence of cloud services}

Based on Rayport \& Heyward's study (2009), they suggested the main enabler or attractiveness of cloud service is the capability, which allows their users to access cloud services whenever and wherever they want without installing any applications. Compared with traditional IT, cloud services give their users seamless access to their information whenever and wherever they want from any device (Lin et al., 2009; Marston et al., 2011; Pallis, 2010). Relying on cloud services, users don't need to always carry their own computing device for using their own information 
or applications; users just simply login on the cloud services via web browser and all their information can be accessed. Moreover, they also have the right to work on, share, and store their information without considering the computing capability limitations of the device which they are using. Thus, omnipresence can be considered as a reasonable enabler for individuals to switch cloud services. The role of omnipresence as an enabler in the context of cloud services has been verified by Park \& Ryoo's study (2013). In this study, we decide to adopt perceived omnipresence instead of omnipresence in order to measure this construct in the perspective of the individual's perception towards cloud services. Even there is few studies to explore the direct influence of perceived omnipresence on individual's switching intention, but considering the positive role of enablers on individual's decision making process suggested by Two-Factor Theory (Herzberg, 1987), we expect that the omnipresence of cloud services perceived by individual has a positive influence on individual's switching intention to cloud services and make the hypothesis as follows.

H1: Perceived omnipresence of cloud services has a positive impact on intention to switch cloud services.

\section{Perceived collaboration support of cloud}

services Besides considering the omnipresence of cloud services as one of the switching enablers,
Miller (2009) suggested the most salient enablers of cloud services is collaboration support. The unique attribute of cloud services - cloud storage capability, provides the possibility of collaboration. As all users' information stored on the cloud servers, if a user is willing to share information with others, he/she can simply store these information in a shared folder and send a link of the shared folder with the specific access permission to these people via E-mail. The people, who have received the E-mail, can obtain the access to the shared folder through simply click the link. There is no doubt the ability for multiple users to easily collaborate on documents and project is one of the most attractive attributes of cloud services. In particular, for the project members, who have significant differences in the working time and working place, will consider cloud services as an ideal solution to help them to overcome the limitations of space and time. With cloud services, anyone can collaborate in real time, anywhere. Thus, collaboration support can be considered as a reasonable enabler for individuals to switch cloud services. The role of collaboration support as an enabler in the context of cloud services has been verified by Park \& Ryoo's study (2013). In this study, we decide to adopt perceived collaboration support instead of collaboration support in order to measure this construct in the perspective of the individual's perception towards cloud services. Even there is few studies to explore the direct influence of perceived collaboration support on individual's 
switching intention, but considering the positive role of enablers on individual's decision making process suggested by two-factor theory (Herzberg, 1987), we expect that the collaboration support of cloud services perceived by individual has a positive influence on individual's switching intention to cloud services and make the hypothesis as follows.

H2: Perceived collaboration support of cloud services has a positive impact on intention to switch cloud services.

\section{Perceived compatibility of cloud services}

Compatibility, one of the five highlighted characteristics, was first proposed to explain diffusion of innovation by Rogers (1983). According to diffusion of innovation theory (DIT; Rogers, 1983), compatibility is the second dimension of DIT and refers to the extent to which the innovation is deemed to be aligned with customer values, past, and potential wants and needs. Al-Majali \& Nik Mat (2011) refers to compatibility as the extent to which the innovation supersedes all other options in meeting the desires and needs of the adopter. It generally refers to the ability of the technology to fit within the lifestyle of the customer. An innovation is more likely to be adopted when it is compatible with an individual's job responsibilities, value, and system (Agarwal \& Prasad, 1997). In this study, compatibility refers to the extent to which the switching to cloud services is considered by the individual as consistent with his/her existing values, beliefs, experiences derived from the usage of incumbent IT. In the context of cloud services, whether the existing office documents can be completely compatible with the cloud services without any distinction and whether the user interface of cloud services can be compatible with the user's past experience derived from the incumbent IT will be the main concerns for the users. The important role of compatibility as an enabler to switch cloud services has been proved in the enterprise level (Lian et al., 2014), but still not clear in the individual level. Hence, we decide to adopt perceived compatibility instead of compatibility in order to measure this construct in the perspective of the individual's perception towards cloud services and expect the compatibility of cloud services perceived by individual has a positive influence on individual's switching intention to cloud services. The hypothesis is generated as follows.

H3: Perceived compatibility of cloud services has a positive impact on intention to switch cloud services.

\subsection{Switching inhibitors and switching intention}

Satisfaction of incumbent IT According to Expectation-Confirmation Theory (ECT), customer's satisfaction are determined by two major constructs: initial expectations 
(pre-purchase) on a product/service and differences between expectations and product/service performances (confirmation). In other words, consumers first develop initial expectations about a specific product/service prior to purchase. Second, their consumption experiences of the product/service will generate the perceived performance towards the product/service. By accessing perceived performance against their frame of reference (i.e. initial expectations), they will determine the extent to which their expectations are confirmed. A customer's expectations are conformed when the product/service perform as much as expected while the expectations are disconfirmed when the product/service performs worse than expected. Confirmation and expectations influence on customer's satisfaction level together, in turn, customer's satisfaction determines customer's repurchase intention. The positive influence of satisfaction on continuance intention has been proved by Expectation-Confirmation Model (ECM; Bhattacherjee, 2001) and lots of ECM-based studies (Chen et al., 2010; Kim, 2010; Lin et al., 2012). Recently, lots of scholars argued that satisfaction also plays an important role on the generation of user's switching intention. Based on Kim et al.'s study (2006), they found that the satisfaction of incumbent E-mail service has a significantly negative influence on the generation of user's intention to switch E-mail services. It means that satisfied users continue using the incumbent IT while dissatisfied users consider switching to a replacement IT. Moreover, the inhibitory effect of satisfaction of incumbent IT on the intention to switch has also been verified by Ye et al.'s study (2008). In other words, when users face a substitute product/service, the level of satisfaction about the incumbent product/service will influence their intention to switch due to their psychological losses. Hence, satisfaction of incumbent IT can be considered as a reasonable inhibitor to prevent individuals from switching to cloud services and we expect the satisfaction of incumbent IT has a negative influence on individual's switching intention to cloud services. The hypothesis is generated as follows.

H4: Satisfaction of incumbent IT has a negative impact on intention to switch cloud services.

Usage habit of incumbent IT Habit is commonly understood as "learned sequences of acts that become automatic response to specific situations which may be functional in obtaining certain goals or end states" (Verplanken et al., 1997). Limayem et al., (2007) refer habit to the extent to which individuals tend to make automatic use of a target IS because of learning effects. Various studies emphasize that the formation of habit is derived from a certain amount of repetition or practice in a given stable environment (Ouellette \& Wood, 1998; Orbell et al., 2001). Prior information systems studies 
related to habitual behavior mainly explore and verify the positive influence of habit on behavioral intention or continuance intention of an incumbent information system (Gefen, 2003; Liao et al., 2006; Kim \& Kwahk, 2007; Cao \& Yin, 2010; Venkatesh et al., 2012). But there is few studies related to habit, focusing on the negative effects of deep-seated habitual behavior towards an incumbent information system on the switching intention to use a new information system. Based on prior studies, the concepts of innovation dissonance (Rogers \& Shoemaker, 1971) and inertia (Barnes et al., 2004) relate to the negative effects of habit. Polites (2005) argued that the habitual use of an old system will negatively affect the use of a new one. Lin et al. (2012) suggested and verified the change of viewing habits is one of the main sacrifices when customers want to switch from traditional cable TV to IPTV. Moreover, Polites \& Karahanna (2012) suggested that incumbent system habit should be considered as one of the main switching inhibitors in the context of switching behavior, besides switching cost and inertia. Hence, the usage habit of incumbent IT can be considered as a reasonable inhibitor to prevent individuals from switching to cloud services as positive effect of the usage habit on the continued use of incumbent technology will lead to a reluctance, which hints at a negative effect of habit on the adoption of a new technology. In this study, we expect that the usage habit of incumbent IT has a negative influence on individual's switching intention to cloud services and make the hypothesis as follows.

H5: Usage habit of incumbent IT has a negative impact on intention to switch cloud services.

Perceived risk of cloud services Based on prior studies, the inhibitors of switching behavior can be caused by both incumbent IT (Park \& Ryoo, 2013) and the alternatives (Hou et al., 2011). From the perspective of the alternatives, perceived risk of cloud services, to some extent, can be considered as a potential inhibitor to decrease user's intention to switch cloud services. The concept of perceived risk was first introduced by Bauer (1960) and defined as the degree to which the customer feels the uncertainty and consequences associated with their actions. The critical role of perceived risk in consumer decision-making has been proved by lots of prior studies (Stone \& Grønhaug, 1993; Pavlou, 2003; Liao et al., 2010). Perceived risk appears when an individual is involved in situations where the outcomes are uncertain and is worried about the consequences of an unsuitable decision (Fraedrich \& Ferrell, 1992). In other words, a person's behavior involves risk if the behavior will produce consequences that he/she can't anticipate with anything approximating certainty and some of which are likely to be undesirable (Bauer, 1960; Liao et al., 2010). Previous studies have revealed that perceived risk negatively 
influenced the willingness to act a risky behavior (Keil et al., 2000) and the perceived risk of online environment is much higher compared with the traditional environment (Wang et al., 2003). Perceived uncertainty and potential monetary loss were found to induce customer's perceived risk towards online behavior (Buttner et al., 2005). On the other hand, lots of scholars argued about the role of perceived risk in the context of individual's switching behavior. Bansal et al. (2005) suggested that low trust of alternatives is one of the critical factors to keep the users from switching to an available alternative. Ye \& potter (2007) found the higher the perceived relative security of incumbent IT is, the less the switching intention will be. Considering the cloud services is one kind of Internet-based services, when users decide to switch cloud services, they have to face the potential risks caused by the adoption of cloud services (i.e. account theft by unauthorized third parties; the leak of personal information). The fears of the potential risks caused by the adoption of cloud services may lead the users to give up switching to cloud services and continue using the incumbent IT instead. Hence, it's reasonable for us to suggest perceived risk of cloud services is one of the inhibitors to prevent individuals from switching to cloud services. In this study, we expect that the perceived risk of cloud services has a negative influence on individual's switching intention to cloud services and make the hypothesis as follows.
H6: Perceived risk of cloud services has a negative impact on intention to switch cloud services.

\subsection{Control variables and switching intention}

User's switching behavior may be influenced by their individual characteristics or outside influences perceived by the user, irrespective of the alternatives under consideration. Hence, the following two variables are controlled in this study.

Social influence Social influence has been traded as analogous to the construct of subjective norms incorporated in the Theory of Reasoned Action (TRA; Ajzen \& Fishbein, 1980) and the Theory of Planned Behavior (TPB; Ajzen, 1991). According to TPB (Azjen, 1991), social influence is defined as "perceived social pressure to perform or not to perform the behavior". In both TRA and TPB, subjective norms has been considered as the antecedent to individual's intention to perform certain behavior. The role of subjective norms or social influence on predicting individual's intention to adopt information technologies has been verified by prior studies (Taylor \& Todd, 1995; Kim, 2010). Moreover, the feasibility to adopt social influence as a control variable in the context of switching behavior has been proved by prior studies (Polites \& Karahanna, 2012; Ye et al., 2008; Park \& Ryoo, 
2013). Therefore, it seems to be reasonable to adopt social influence as a control variable in this study.

Personal innovativeness Rogers (1995) argued that individual's innovativeness is a crucial determinant affecting adoption behavior for new technologies. Innovativeness can be defined as the degree to which an individual makes innovation decisions independently of communicated experience of others (Midgely \& Dowling, 1978). Innovativeness helps to identify individuals who are likely to adopt information technology innovations earlier than others (Agarwal \& Prasad, 1999). Many existing studies suggest that innovativeness has an important influence on the adoption of new technologies (Agrawal \& Prasad, 1998; Lin, 1998; Hung et al., 2003; Yang, 2005). Kuo \& Yen (2009) have argued that greater individual's innovativeness leads to more positive acceptance intention of new technologies. Moreover, Park \& Ryoo (2013) have suggested and verified that greater individual's personal innovativeness leads to more positive switching intention in the context of switching behavior. Based on these findings, it's reasonable for us to adopt personal innovativeness as a control variable in this study. Even we adopt personal innovativeness and social influence as control variables in this study, but we don't introduce formal hypotheses for them.

\section{Research design}

\subsection{Research model}

The approach for our research model is mainly constructed based on Two-Factor Theory. In particular, the switching enablers include perceived omnipresence of cloud services, perceived collaboration support of cloud services and perceived compatibility of cloud services as well as switching inhibitors include satisfaction of incumbent IT, usage habit of incumbent IT and perceived risk of cloud services. Control variables include personal innovativeness and social influence. Drawing upon the established theories and prior empirical findings, we proposed a research model shown in $<$ Figure $1>$.

\subsection{Construct operationalization}

In this study, we build a research model included 9 constructs, which are measured by 30multiple items with a five-point Likert-type scale ranging from "Strongly disagree" to "Strongly agree". All the items used in this study are developed from suggested and validated measurements based on previous studies. Considering the complexity of focusing on all kinds of incumbent IT and cloud services existed in China, we choose Microsoft office to represent the incumbent IT and choose Google Drive to represent the cloud services, respectively. Moreover, as both Microsoft office and Google 


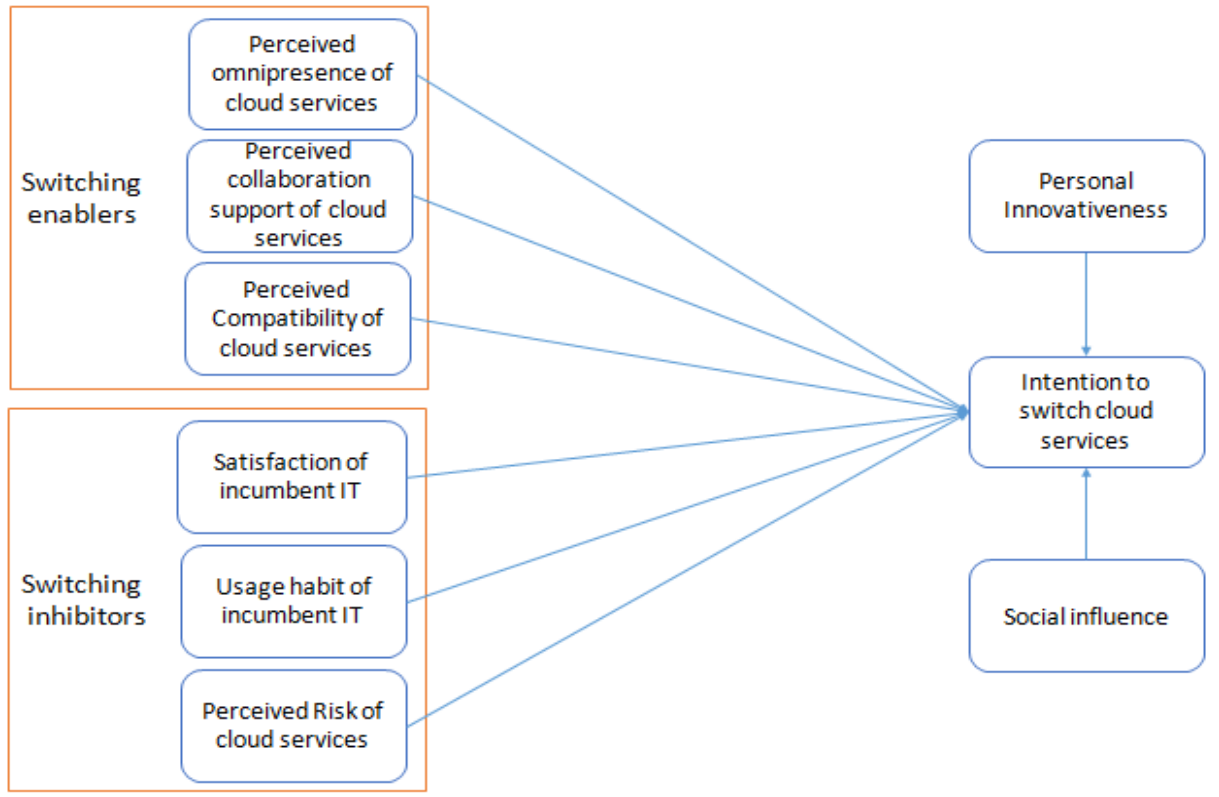

<Figure 1> Research Model

Drive has a huge user base in China, it will be more convenient for us to collect data. Hence, all these items are slightly modified to relate specifically individual's switching behavior from Microsoft office to Google Drive.

Perceived omnipresence of cloud services is measured by 4-item scale based on Park \& Ryoo's study (2013). The items in this scale are used to examine the extent to which an individual believes he/she can access to Google Drive anywhere/anytime, given their access to the Internet. Perceived collaboration support of cloud services is measured by 4 -item scale also based on Park \& Ryoo's study (2013). The items in this scale are used to examine the extent to which an individual believes his/her expected collaborative interaction will be achieved via Google Drive. Perceived compatibility of cloud services is measured by 3 -item scale based on Lian et al.'s study (2014). The items in this scale are used to examine the extent to which an individual believes the switching to Google Drive is consistent with his/her existing values, beliefs, experiences derived from the usage of Microsoft office. Satisfaction of incumbent IT is measured by 3-item scale based on Bhattacherjee's study (2001). The items in this scale are used to examine the extent to which an individual perceives a positive affective state resulting from an overall evaluation of performance based on his/her past usage experience of Microsoft office. Usage habit of Incumbent IT is measured by 3 -items based on Kang et al.'s study (2013). The items in this scale are used to examine the extent to which using Microsoft office has become automatic in response to certain situations. Perceived risk of 
cloud services is measured by 3 -item scale based on Belanche et al.'s study (2012). The items in this scale are used to examine the extent to which an individual feels the uncertainty and consequences associated with their switching actions to Google Drive. Social influence is measured by 3 -item scale based on Kim's study (2010). The items in this scale are used to examine the extent to which an individual's behavioral choice of switching to Google Drive will be influenced by his/her key referent groups, such as peers or coworkers. Personal innovativeness is measured by 4 -item scale based on Kuo \& Yen's study (2009). The items in this scale are used to examine the extent to which an individual makes innovation decision to switch Google Drive independently of communicated experience of others. Intention to switch cloud services is measured by 3 -item scale based on Bhattacherjee's study (2001). The items in this scale are used to examine the extent to which an individual is willing to switch Google Drive. The details of each item and related previous studies are arranged in $<$ Table $1>$ as follows.

$<$ Table 1> -Questionnaire Development

\begin{tabular}{|c|c|c|}
\hline Construct & Questionnaire & Literature \\
\hline \multirow{4}{*}{$\begin{array}{c}\text { Perceived } \\
\text { omnipresence } \\
\text { of cloud services } \\
\text { (POM) }\end{array}$} & $\begin{array}{l}\text { I believe I can use Google Drive anytime and anywhere, given that I } \\
\text { have access to Internet. }\end{array}$ & \multirow{4}{*}{ Park \& Ryoo (2013) } \\
\hline & $\begin{array}{l}\text { I would find Google Drive to be easily accessible, given that I have } \\
\text { access to Internet. }\end{array}$ & \\
\hline & $\begin{array}{l}\text { I believe it is possible to instantly use Google Drive, given that I have } \\
\text { access to Internet. }\end{array}$ & \\
\hline & I believe Google Drive would be available to use whenever I need it. & \\
\hline \multirow{4}{*}{$\begin{array}{c}\text { Perceived } \\
\text { collaboration } \\
\text { support } \\
\text { of cloud service } \\
\text { (PCS) }\end{array}$} & $\begin{array}{l}\text { I think the extent of collaborative interaction among users } \\
\text { would be increased through Google Drive. }\end{array}$ & \multirow{4}{*}{$\begin{array}{l}\text { Park } \\
(2013)\end{array}$} \\
\hline & $\begin{array}{l}\text { I think the extent of sharing information among team members would } \\
\text { be increased through Google Drive. }\end{array}$ & \\
\hline & $\begin{array}{l}\text { I think the openness to share data among team members would be } \\
\text { increased through Google Drive. }\end{array}$ & \\
\hline & $\begin{array}{l}\text { Overall, I think the extent of collaboration would be increased through } \\
\text { Google Drive. }\end{array}$ & \\
\hline \multirow{3}{*}{$\begin{array}{c}\text { Perceived } \\
\text { compatibility of } \\
\text { cloud services } \\
\text { (PCO) }\end{array}$} & $\begin{array}{l}\text { I think Google Drive is compatible with my current experiences } \\
\text { derived from the usage of Microsoft office. (i.e. keyboard shortcuts } \\
\text { support) }\end{array}$ & \multirow{3}{*}{ Lian et al. (2014) } \\
\hline & $\begin{array}{l}\text { I think Google Drive is compatible with my existing values derived } \\
\text { from the usage of Microsoft office. (i.e. existing documents support) }\end{array}$ & \\
\hline & $\begin{array}{l}\text { I think Google Drive is compatible with my existing beliefs derived } \\
\text { from the usage of Microsoft office. (i.e. expected functions support) }\end{array}$ & \\
\hline Satisfaction of & Using Microsoft office makes me feel satisfied. & Bhattacherjee (2001) \\
\hline
\end{tabular}




\begin{tabular}{|c|c|c|}
\hline Construct & Questionnaire & Literature \\
\hline \multirow{2}{*}{$\begin{array}{l}\text { incumbent IT } \\
\text { (SN) }\end{array}$} & Using Microsoft office makes me feel pleased. & \\
\hline & Overall, I am satisfied with my experience with Microsoft office. & \\
\hline \multirow{3}{*}{$\begin{array}{l}\text { Usage habit of } \\
\text { incumbent IT } \\
\qquad(\mathrm{HT})\end{array}$} & Using Microsoft office has become automatic to me. & \multirow{3}{*}{ Kang et al. (2013) } \\
\hline & Using Microsoft office is natural to me. & \\
\hline & $\begin{array}{l}\text { When faced with a particular task, using Microsoft office is an obvious } \\
\text { choice for me. }\end{array}$ & \\
\hline \multirow{3}{*}{$\begin{array}{l}\text { Perceived risk } \\
\text { of cloud services } \\
\qquad(\mathrm{PR})\end{array}$} & $\begin{array}{l}\text { Using Google Drive may cause me to be concerned with experiencing } \\
\text { some kind of loss in the future. }\end{array}$ & \multirow{3}{*}{ Belanche et al. (2012) } \\
\hline & I will become vulnerable if I decide to use Google Drive. & \\
\hline & $\begin{array}{l}\text { The adoption of Google Drive may cause problems and uncertain } \\
\text { consequences for me. }\end{array}$ & \\
\hline \multirow{3}{*}{$\begin{array}{l}\text { Social } \\
\text { influence } \\
\text { (SI) }\end{array}$} & $\begin{array}{l}\text { People who influence my behavior (friends, colleagues, etc.) } \\
\text { think that I should use Google Drive. }\end{array}$ & \multirow{3}{*}{$\operatorname{Kim}(2010)$} \\
\hline & $\begin{array}{l}\text { People who influence my behavior (friends, colleagues, etc.) } \\
\text { think that I should switch from Microsoft office to Google } \\
\text { Drive. }\end{array}$ & \\
\hline & $\begin{array}{l}\text { People who influence my behavior (friends, colleagues, etc.) } \\
\text { expect me to switch from Microsoft office to Google Drive. }\end{array}$ & \\
\hline \multirow{4}{*}{$\begin{array}{l}\text { Personal } \\
\text { innovativeness } \\
\text { (PI) }\end{array}$} & $\begin{array}{l}\text { If I heard about a new information technology, I would look for ways } \\
\text { to experiment with it. }\end{array}$ & \multirow{4}{*}{ Kuo \& Yen (2009) } \\
\hline & $\begin{array}{l}\text { Among my peers, I am usually the first to try out new information } \\
\text { technologies. }\end{array}$ & \\
\hline & In general, I am not hesitant to try out new information technologies. & \\
\hline & I like to experiment with new information technologies. & \\
\hline \multirow{3}{*}{$\begin{array}{l}\text { Intention to } \\
\text { switch cloud } \\
\text { services } \\
\text { (ITS) }\end{array}$} & I intend to increase my use of Google Drive in the foreseeable future. & \multirow{3}{*}{ Bhattacherjee (2001) } \\
\hline & I intend to invest my time and effort to Google Drive. & \\
\hline & I intend to switch from Microsoft office to Google Drive. & \\
\hline
\end{tabular}

\subsection{Data collection}

We conducted a survey from September 2013 to December 2013 in a large public university, located in Beijing. The students were probed for their switch intention from Microsoft office to Google Drive and only those who had the experiences of both Microsoft office and Google Drive were given the questionnaire. In total, 277 respondents were answered and 21 respondents were discarded due to insincere responses. Finally, 256 respondents were used for analysis in this study. Among the respondents, 58\% were male, $42 \%$ were female. $61 \%$ of the respondents 
were undergraduate students, $22 \%$ graduate students, and $17 \%$ doctoral students. In terms of age, $26 \%$ of the respondents were younger than 20 and $74 \%$ were ranged from 20 to 29 years old.

\section{Data analysis}

\subsection{Validity \& Reliability analysis of research model}

In order to identify the validity and reliability of the measurement of the research model in this study, we adopt confirmatory factor analysis \& reliability test, convergent validity test and discrimination validity test. As shown in $<$ Table
$2>$, all the values of completely standardized factor loading ranged from 0.769 to 0.881 have reached the significant level compared with the lowest acceptance level of 0.50. Meanwhile, all the values of Cronbach's a for each construct ranged from 0.825 to 0.898 are larger than 0.60 , all the squared multiple correlations (SMC) of the measured items ranged from 0.570 to 0.829 are larger than 0.50 and the composite reliability (CR) of all the measured items ranged from 0.840 to 0.924 are extremely higher than the lowest acceptance level of 0.60 indicating that the measurement of the research model in this study have a good reliability (Bagozzi \& Yi, 1988; Hair et al., 1998).

$<$ Table 2> Confirmatory Factor Analysis \& Reliability Test \& Convergent Validity Test

\begin{tabular}{|c|c|c|c|c|c|c|}
\hline Construct & Item & $\begin{array}{c}\text { Standardized } \\
\text { Factor Loading }\end{array}$ & Cronbach's a & SMC & $\mathrm{CR}$ & AVE \\
\hline \multirow{4}{*}{$\begin{array}{c}\text { Perceived } \\
\text { omnipresence } \\
\text { of cloud services }\end{array}$} & POM 1 & 0.836 & \multirow{4}{*}{0.872} & 0.738 & \multirow{4}{*}{0.882} & \multirow{4}{*}{0.652} \\
\hline & POM 2 & 0.769 & & 0.570 & & \\
\hline & POM 3 & 0.771 & & 0.597 & & \\
\hline & POM 4 & 0.850 & & 0.631 & & \\
\hline \multirow{4}{*}{$\begin{array}{c}\text { Perceived } \\
\text { collaboration } \\
\text { support } \\
\text { of cloud service }\end{array}$} & PCS 1 & 0.861 & \multirow{4}{*}{0.885} & 0.713 & \multirow{4}{*}{0.896} & \multirow{4}{*}{0.682} \\
\hline & PCS 2 & 0.793 & & 0.595 & & \\
\hline & PCS 3 & 0.799 & & 0.635 & & \\
\hline & PCS 4 & 0.849 & & 0.700 & & \\
\hline \multirow{3}{*}{$\begin{array}{c}\text { Perceived } \\
\text { compatibility of } \\
\text { cloud services }\end{array}$} & PCO 1 & 0.782 & \multirow{3}{*}{0.894} & 0.829 & \multirow{3}{*}{0.840} & \multirow{3}{*}{0.637} \\
\hline & PCO 2 & 0.811 & & 0.772 & & \\
\hline & PCO 3 & 0.801 & & 0.634 & & \\
\hline \multirow{3}{*}{$\begin{array}{l}\text { Satisfaction of } \\
\text { incumbent IT }\end{array}$} & SN 1 & 0.861 & \multirow{3}{*}{0.877} & 0.683 & \multirow{3}{*}{0.899} & \multirow{3}{*}{0.748} \\
\hline & SN 2 & 0.881 & & 0.813 & & \\
\hline & SN 3 & 0.853 & & 0.636 & & \\
\hline \multirow{3}{*}{$\begin{array}{l}\text { Usage habit of } \\
\text { incumbent IT }\end{array}$} & HT 1 & 0.863 & \multirow{3}{*}{0.858} & 0.732 & \multirow{3}{*}{0.900} & \multirow{3}{*}{0.743} \\
\hline & HT 2 & 0.866 & & 0.633 & & \\
\hline & HT 3 & 0.857 & & 0.648 & & \\
\hline
\end{tabular}




\begin{tabular}{|c|c|c|c|c|c|c|}
\hline Construct & Item & $\begin{array}{c}\text { Standardized } \\
\text { Factor Loading }\end{array}$ & Cronbach's a & SMC & $\mathrm{CR}$ & AVE \\
\hline \multirow{3}{*}{$\begin{array}{l}\text { Perceived risk } \\
\text { of cloud services }\end{array}$} & PR 1 & 0.823 & \multirow{3}{*}{0.846} & 0.682 & \multirow{3}{*}{0.878} & \multirow{3}{*}{0.706} \\
\hline & PR 2 & 0.869 & & 0.667 & & \\
\hline & PR 3 & 0.828 & & 0.596 & & \\
\hline \multirow{3}{*}{$\begin{array}{c}\text { Social } \\
\text { influence }\end{array}$} & SI 1 & 0.859 & \multirow{3}{*}{0.825} & 0.599 & \multirow{3}{*}{0.887} & \multirow{3}{*}{0.724} \\
\hline & SI 2 & 0.853 & & 0.672 & & \\
\hline & SI 3 & 0.840 & & 0.583 & & \\
\hline \multirow{4}{*}{$\begin{array}{c}\text { Personal } \\
\text { Innovativeness }\end{array}$} & PI1 & 0.878 & \multirow{4}{*}{0.898} & 0.666 & \multirow{4}{*}{0.924} & \multirow{4}{*}{0.754} \\
\hline & PI2 & 0.859 & & 0.698 & & \\
\hline & PI3 & 0.860 & & 0.704 & & \\
\hline & PI4 & 0.875 & & 0.682 & & \\
\hline \multirow{3}{*}{$\begin{array}{l}\text { Intention to switch } \\
\text { cloud services }\end{array}$} & ITS 1 & 0.786 & \multirow{3}{*}{0.871} & 0.678 & \multirow{3}{*}{0.842} & \multirow{3}{*}{0.639} \\
\hline & ITS 2 & 0.819 & & 0.614 & & \\
\hline & ITS 3 & 0.793 & & 0.739 & & \\
\hline
\end{tabular}

Moreover, as shown in $<$ Table 3>, each measured constructs has an average variance extracted (AVE) above 0.50 also indicated that a good convergent validity could be obtained (Fornell \& Larcker, 1981). Each measured construct's AVE is larger than the squared correlation values between each pair of constructs. So the discrimination validity is also adequate for the measurement of the research model in this study (Fornell \& Larcker, 1981). Based on these test results of validity and reliability, the measurement of the research model in this study can be accepted.

$<$ Table 3> Discrimination Validity Test of Research Model

\begin{tabular}{|c|c|c|c|c|c|c|c|c|c|}
\hline & POM & PCS & PCO & SN & HT & PR & SI & PI & ITS \\
\hline POM & $\mathbf{0 . 8 0 7}$ & & & & & & & & \\
\hline PCS & 0.384 & $\mathbf{0 . 8 2 6}$ & & & & & & & \\
\hline PCO & 0.556 & 0.482 & $\mathbf{0 . 7 9 8}$ & & & & & & \\
\hline SN & -0.093 & -0.153 & -0.039 & $\mathbf{0 . 8 6 5}$ & & & & & \\
\hline HT & -0.039 & -0.030 & -0.005 & 0.257 & $\mathbf{0 . 8 6 2}$ & & & & \\
\hline PR & -0.010 & 0.095 & -0.136 & 0.405 & 0.234 & $\mathbf{0 . 8 4 0}$ & & & \\
\hline SI & 0.072 & 0.124 & 0.173 & -0.020 & -0.096 & -0.057 & $\mathbf{0 . 8 5 1}$ & & \\
\hline PI & 0.107 & 0.200 & 0.053 & -0.064 & -0.025 & -0.093 & 0.117 & $\mathbf{0 . 8 6 8}$ & \\
\hline ITS & 0.359 & 0.301 & 0.437 & -0.178 & -0.324 & -0.262 & 0.307 & 0.260 & $\mathbf{0 . 7 9 9}$ \\
\hline
\end{tabular}




\subsection{Model fit analysis of research model}

$<$ Table $4>$ shows the results of Goodness Fit Index for measurement model and structural model of this study. From the fit indices, we can know that the research model suggested in this study is appropriate to estimate the relationships among all these constructs, as the results with satisfactory levels including Chi-square/degrees of freedom $\left(\mathrm{X}^{2} / \mathrm{DF}\right)$, root mean square residual (RMR), goodness-of-fit (GFI), adjusted goodness-of-fit (AGFI), parsimony goodness of fit (PGFI), normalized fit index (NFI), root mean square error of approximation (RMSEA) and comparative fit index (CFI). Comparison of all fit indices with their corresponding recommended values (Hair et al. 1998), the evidence of a good model fit can be revealed.

$<$ Table 4> Model Fit Analysis of Research Model

\begin{tabular}{|c|c|c|c|c|}
\hline \multicolumn{2}{|c|}{ Fit Indices } & Measurement Indices & Structural Indices & Recommended \\
\hline \multirow{4}{*}{$\begin{array}{c}\text { Absolute Fit } \\
\text { Indices }\end{array}$} & $\mathrm{X}^{2}$ /DF & 1.146 & 1.160 & $<3.000$ \\
\cline { 2 - 5 } & GFI & 0.904 & 0.901 & $>0.900$ \\
\cline { 2 - 5 } & AGFI & 0.880 & 0.879 & $>0.800$ \\
\cline { 2 - 5 } & NFI & 0.911 & 0.906 & $>0.900$ \\
\cline { 2 - 5 } & PFI & 0.987 & 0.986 & $>0.900$ \\
\cline { 2 - 5 } & RMFI & 0.718 & 0.740 & $>0.600$ \\
\cline { 2 - 5 } & RMSEA & 0.040 & 0.059 & $<0.080$ \\
\hline
\end{tabular}

\subsection{Hypotheses test}

In this study, the estimated path coefficients of the structural model can be used to confirm the hypotheses. Both $<$ Figure $2>$ and $<$ Table $5>$ show the standard path coefficients and significant level of each hypothesis included in this study. Based on $<$ Figure $2>$, all these hypotheses can be supported except $\mathrm{H} 4$ and the hypothesis discussions are shown as follows.

(1) the generation of intention to switch from switching enablers
In the perspective of switching enablers, as perceived omnipresence of cloud services $(\mathrm{\gamma}=$ $0.199 ; *)$, perceived collaboration support of cloud services $(\gamma=0.155 ; *)$ and perceived compatibility of cloud services $\left(\gamma=0.224 ;^{*}\right)$ have significantly positive influences on the generation of intention to switch Google Drive, hypotheses H1, H2, and H3 could be accepted. Among these switching enablers, perceived compatibility of cloud services $(\gamma=0.224 ; *)$ has the strongest influence on the generation of intention to switch Google Drive, followed by 


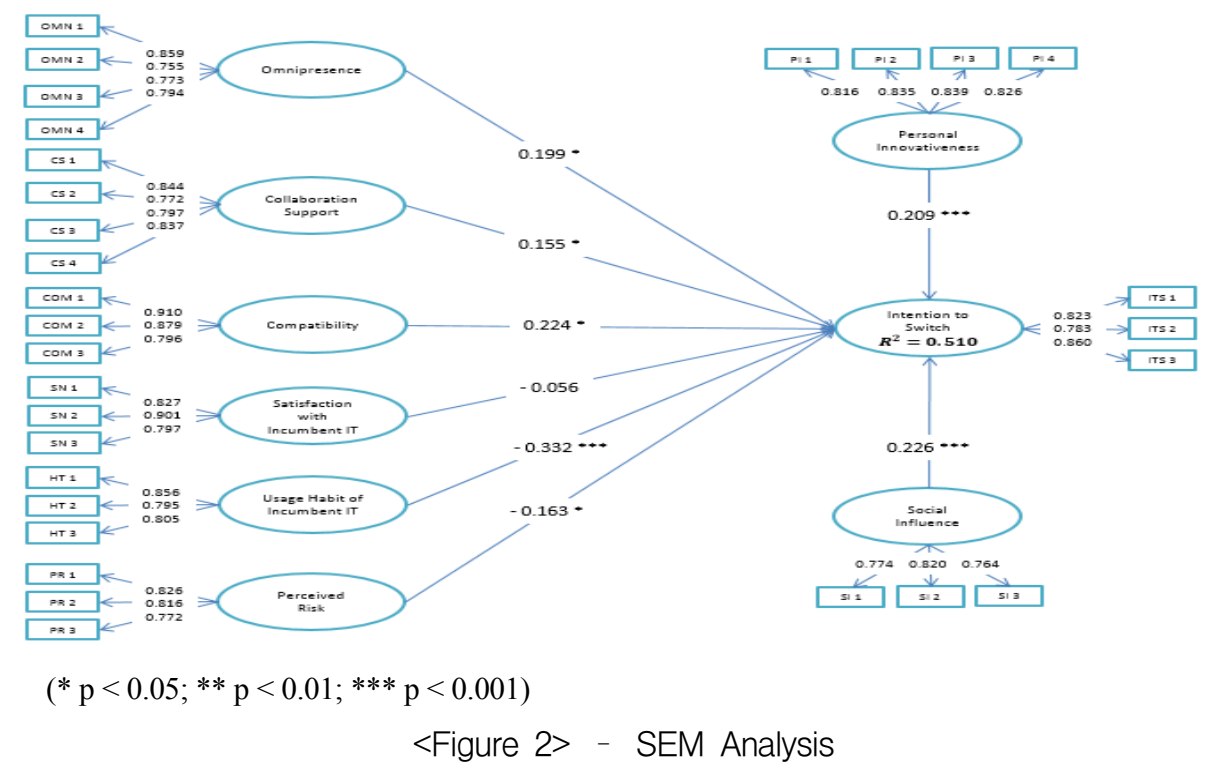

perceived omnipresence of cloud services $(\gamma=$ $\left.0.199 *^{*}\right)$ and perceived collaboration support of cloud services $(\gamma=0.155 ; *)$. As we conduct the survey in a public university, the respondents students, more or less, have some existing electronic documents generated by Microsoft office; these electronic documents may include class handouts, team projects, homework, etc. Hence, whether these existing electronic documents are compatible with the Google Drive or not is the thing that the students may most care about. If these electronic documents can't work in Google Drive exactly the same as in Microsoft office or even can't be opened in Google Drive at all, the students are less likely to switch to Google Drive. Moreover, whether the Google Drive is compatible with the experiences and beliefs derived from the usage of Microsoft office also plays an important role on the generation of intention to switch Google Drive. For instance, students can easily copy and paste a sentence via keyboard shortcuts $(\mathrm{Ctrl}+\mathrm{C} \& \mathrm{Ctrl}+\mathrm{V})$, they may expect these useful skills still can be used in the Google Drive. The more compatibility students can perceive from Google Drive, the more likely for the students to switch Google Drive. On the other hand, perceived omnipresence $(\mathrm{\gamma}=0.199 ; *)$ of cloud service, which represents the flexibility on the time and space for a user to access Google Drive, occupies the second place to generate user's intention to switch. It indicates that the users expect they can access the Google Drive anytime/anywhere from any supported devices, given the access to the Internet. In the context of university, the students may want to establish a mobile learning environment through Google Drive to reduce the dependency of university's infrastructure or enjoy a more convenient learning style. For instance, the students can easily find a place to study 
without consideration of the necessary PC support in the university and instead, they can access their learning materials via Google Drive from their Smartphone or Tablet-PC. Hence, the perceived omnipresence of cloud services plays an important role on the generation of intention to switch Google Drive in this study. Moreover, although Miller (2009) suggested that collaboration support is the most attractive attribute of cloud services, but the influence of perceived collaboration support of cloud services $(\mathrm{\gamma}=0.155 ; *)$ on the generation of intention to switch Google Drive is not as significant as we expected. In the context of university, the occasion required the continuous collaboration within a group/team is limited, compared with the situations of enterprise workplace. For most of the university students in China, they pay no attention to the importance of teamwork and also have very few experiences about teamwork due to the disadvantages of China's education system. Thus, the importance of the unique attribute on Google Drive may not be fully perceived by the students and their perceived collaboration support of Google Drive may stay at the "information sharing" level, which will weaken the influence of perceived collaboration support of Google Drive on the generation of intention to switch Google Drive.

(2) the generation of intention to switch from switching inhibitors

In the perspective of switching inhibitors, satisfaction of incumbent IT $(\mathrm{\gamma}=-0.056 ; 0.405)$ has an insignificant influence on the generation of intention to switch cloud services, which means H4 can't be accepted in this study. This result is inconsistent with the result derived from Ye et al.'s study (2008). Some scholars argued that there was a moderating effect of perceived value between satisfaction and continuance intention (Chang et al. 2009). When the perceived value is low, customers will be more inclined to switch to an available alternative in order to increase perceived value, thus contributing to a decline in continuance behavior. In the context of E-business, even satisfied customers are unlikely to patronize an e-business, if they feel that they are not getting the best value for their money. Instead, they will seek out other sellers in an ongoing effort to find a better value (Anderson \& Srinivasan, 2003; Chang, 2006). The relationship between customer satisfaction and their continuance intention appears strongest when the customers feel that their incumbent IT provides higher overall value than that offered by other available alternatives and appears weakest when the customers feel that their incumbent IT provides lower overall value than that offered by other available alternatives (Chang et al., 2009). As the respondents in this study are those who have the experiences of both Microsoft office and Google Drive, they may have already formed their own perceived overall value by considering both sides. when users feel that Microsoft office provides lower overall value than that offered by Google 
Drive, not only the low satisfaction users with Microsoft office but also the high satisfaction users with Microsoft office will be more likely to switch Google Drive in order to increase the overall value; when users feel that Microsoft office provides higher overall value than that offered by Google Drive, not only the high satisfaction users with Microsoft office but also the low satisfaction users with Microsoft office will be more likely to continuous use Microsoft office as the switching behavior can't bring them more overall value. This might be reasonable to explain why satisfaction of incumbent IT has an insignificant influence on the generation of intention to switch cloud services in this study. On the other hand, usage habit of incumbent IT ( $\mathrm{\gamma}=$ $-0.332 ; * * *)$ has a significant influence on the generation of intention to switch cloud services. This finding can be considered as a strong evidence to support that usage habit of incumbent IT has a negative influence on the intention to switch available IT (Polites, 2005; Polites \& Karahanna, 2012). Among these switching inhibitors, the usage habit of incumbent IT plays the most important role on the generation of intention to switch cloud services, compared with satisfaction of incumbent IT ( $\gamma=-0.056 ; 0.405)$ and perceived risk of cloud services $(\mathrm{\gamma}=-0.163$; *). Moreover, the inhibitory effect of perceived risk $(\gamma=-0.163 ; *)$ of cloud services on the generation of intention to switch cloud services has also been verified, which indicates the students are risk aversion and they try to avoid the potential loss and uncertainty caused by switching to Google Drive. In the context of cloud services, considering all user's information will be stored in the cloud servers, the students have to suffer from the potential risks (i.e. the illegal modification of personal information or insufficient access to their personal information caused by the network infrastructure faults), which may result in the decline of their intention to switch cloud services.

(3) the generation of intention to switch from control variables

In the perspective of control variables, personal innovativeness $(\mathrm{\gamma}=0.209 ; * * *)$ has $\mathrm{a}$

$<$ Table 5> Results of Hypothesis Test

\begin{tabular}{|c|c|l|c|c|l|}
\hline Hypothesis & \multicolumn{1}{|c|}{ Path } & Path Coefficient & S.E. & T Value & \multicolumn{1}{|c|}{$\begin{array}{c}\text { Hypothesis } \\
\text { Test }\end{array}$} \\
\hline H1 & POM $\rightarrow$ ITS & $0.199 *$ & 0.085 & 2.557 & Accepted \\
\hline H2 & PCS $\rightarrow$ ITS & $0.155 *$ & 0.069 & 2.116 & Accepted \\
\hline H3 & PCO $\rightarrow$ ITS & $0.224 *$ & 0.095 & 2.552 & Accepted \\
\hline H4 & SN $\rightarrow$ ITS & -0.056 & 0.071 & -0.832 & Rejected \\
\hline H5 & HT $\rightarrow$ ITS & $-0.332 * * *$ & 0.072 & -5.173 & Accepted \\
\hline H6 & PR $\rightarrow$ ITS & $-0.163 *$ & 0.080 & -2.331 & Accepted \\
\hline
\end{tabular}


significantly positive influence on the generation of intention to switch cloud services. Many existing studies suggest that innovativeness has a positive influence on the adoption of new technologies (Agrawal \& Prasad, 1998; Lin, 1998). This finding can provide an evidence to support that personal innovativeness also plays an important role on user's switching intention from status quo to new technologies. Moreover, social influence $(\mathrm{\gamma}=0.226 ; * * *)$ has a significantly positive influence on the generation of intention to switch cloud services. In the context of university, the students seem to be more likely to switch cloud services when their friends or team members suggest them to.

\section{Implications}

\subsection{Implications for academic researchers}

This study makes four substantial contributions to understand individual's switching behavior in the context of cloud services. First, this study adopt two-factor theory as the conceptual framework and explore the potential key factors which may directly affect individual's switching intention to cloud services in the perspective of both switching enablers and switching inhibitors, as the adoption of a double-barreled model seems to be more meaningful to provide a deeper insight to understand individual's switching behavior (Ye et al., 2008; Park \& Ryoo, 2013). In fact, we do obtain an appropriate explanation of variance in intention to switch cloud services according to the acceptable level of the R-square $\left(R^{2}=0.510\right)$ in this study. Second, considering all the switching enablers in this study are abstracted from the unique attributes of cloud services by comparing with the traditional IT and, to some extent, can be used to represent the relative advantage for users to switch cloud services in this study. Hence, we expect the higher the relative advantage of cloud services perceived by the users, the more likely their intention to switch cloud services will be. As we expected, all of the switching enablers (perceived omnipresence of cloud services, perceived collaboration support of cloud services and perceived compatibility of cloud services) have the directly positive influences on the generation of intention to switch cloud services. Third, in the perspective of switching inhibitors, usage habit of incumbent IT and perceived risk of cloud services have been found negatively impact on the generation of intention to switch cloud services. But it is noteworthy that satisfaction with incumbent IT has an insignificant influence on the generation of intention to switch cloud services, which is against the findings in Ye et al.'s study (2008). Last, the role of personal innovativeness and social influence has been empirically confirmed in the context of switching behavior. 


\subsection{Implications for cloud service practitioners}

This study also provides several important implications for the practitioners of cloud services. First, as all the switching enablers have significant influences on the generation of user's intention to switch cloud services, the enhancement of omnipresence, collaboration support and compatibility perceived by the users will be helpful to induce their switching behavior to cloud services. Accordingly, providing the unified user experience across different devices, more convenient or easier collaboration way and more familiar user interface will be helpful to induce user's switching behavior to cloud services. Second, as the switching inhibitors have significant influences on the generation of user's intention to switch cloud services, the reduction of user's perceived risk of cloud services and usage habit of incumbent IT will be also helpful to induce their switching behavior to cloud services. To overcome the influence of the usage habit of incumbent IT, the practitioners of cloud services can offer various incentives, value-added services and personalized services to promote individual's cloud services usage. For instance, providing extra data space as reward to the users who invite their friends or coworkers to experience the cloud services or allowing the users to customize the cloud services based on their usage experiences of incumbent IT to develop the most suitable usage environment for themselves. On the other hand, to decrease the influence of the perceived risk of cloud services, the practitioners of cloud services can offer more robust security mechanisms and more humane, user-defined functions. For instance, allowing the cloud services to automatically sync information to user's router which has the embedded hard disk (Network Attached Storage). Finally, considering the important role of personnel innovativeness and social influence on user's intention to switch cloud services, providing official supported forum to get users' feedback information or providing road show (i.e. campus presentation) to the most Innovative group (i.e. university students) also will be an effective approach.

\section{Conclusion}

This study aims to find out the factors which directly affect individual's switching intention to cloud services. According to the analysis results, our study has the follow contributions. First, the adoption of Two-Factor Theory as the conceptual framework in this study is helpful to understand and predict individual's switching behavior in the context of cloud services. Second, the components of switching enablers in this study, abstracted from the unique attributes of cloud services, are found to have directly positive influences on the generation of individual's switching intention to cloud services. Third, the 
components of switching inhibitors, adopted from prior studies, are found to have directly negative influences on the generation of individual's switching intention to cloud services, except the satisfaction of incumbent IT. Finally, the positive role of personal innovativeness and social influence on the generation of individual's switching intention has also been confirmed in this study.

Even though this study succeeds in validating the research model, but there are still some limitations of our study that we point out the following issues. First, as all the data for our study are collected from university students, located in Beijing. It means that the generalization of the findings in this study could be restricted. Hence, future study is needed to verify the findings in this study based on a wider range of sample composition, which includes both university students and enterprise workers. Second, even the main concern of this study is focused on individual's switching behavior, but, in fact, individuals can adopt either Microsoft office or Google Drive based on the specific usage context. If users are working on some team works, they may be more likely to adopt Google Drive; otherwise, they may prefer to adopt Microsoft office. Hence, the effect of usage context should be controlled in the future study. Third, considering only 256 respondents are adopted in this study, how the findings in this study are sensitive with the sample size will be verified in the future study through a more sufficient and comprehensive sample composition.

\section{References}

Agarwal, R., \& Prasad, J., "The role of innovation characteristics and perceived voluntariness in the acceptance of information technologies", Decision Sciences, Vol.28, No.3, 1997, pp.557-582.

Agarwal, R., \& Prasad, J., "A conceptual and operational definition of personal innovativeness in the domain of information technology", Information Systems Research, Vol.9, No.2, 1998, pp.204-215.

Agarwal, R., \& Prasad, J., "Are individual differences germane to the acceptance of new technologies?", Decision Sciences, Vol.30, No.2, 1999, pp.361-391.

Ajzen, I., \& Fishbein, M., "Understanding attitudes and predicting social behavior", Englewood Cliffs, NJ: Prentice-Hall, 1980.

Ajzen, I., "The theory of planned behavior", Organizational Behavior and Human Decision Process, Vol.50, No.2, 1991, pp.179-211.

AL-Majali, M., \& Nik Mat, N.K., "Modeling the Antecedents of Internet Banking Service Adoption (IBSA) in Jordan: A Structural Equation Modeling (SEM) approach", Journal of Internet Banking and Commerce, Vol.16, No.1, 2011, pp.1-15.

Anderson, R.E., \& Srinivasan, S.S., 
"E-satisfaction and e-loyalty: A contingency framework", Psychology \& Marketing, Vol.20, No.2, 2003, pp.123138.

Bagozzi, R. P., \& Yi, Y., "On the evaluation of structural equation models", Journal of the Academy of Marketing Science, Vol. 16, No. 1, 1988, pp. 74-94.

Bansal, H. S., Taylor, S. F., \& James, Y. S., " 'Migrating' to new service providers: Toward a unifying framework of consumers' switching behaviors", Journal of the Academy of Marketing Science, Vol.33, No.1, 2005, pp.96-115.

Barnes, W., Gartland, M., \& Stack, M., "Old habits die hard: Path dependency and behavioral lock-in", Journal of Economic Issues, Vol.38, No.2, 2004, pp.371-378.

Bauer, R. A., "Consumer behavior at risk taking", Proceedings, American Marketing Association, 1960.

Belanche, D., Casalo', L. V., Guinalı'u, M., "Website usablity consumer satisfaction and the intention to use a website: The moderating effect of perceived risk", Journal of Retailing and Consumer Services, Vol.19, No.1, 2012, pp.124-132.

Bhattacherjee, A., "Understanding information systems continuance. An expectation-confirmation model", Mis Quarterly, Vol.25, No.3, 2001, pp.351370.

Buttner, O. B., Schulz, S., \& Silberer, G.,
"Perceived risk and deliberation in retailer choice: Consumer behavior towards online pharmacies", Advances in Consumer Research, Vol.33, 2005, pp.197-202.

Cao, S.-Y., \& Yin, H.-X., "Trust and Habit in E-Service Continuance: An Integrated Model", Journal of Computational Information Systems, Vol.6, No.11, 2010, pp.3595-3604.

Cenfetelli, R. T., \& Schwarz, A. (in press). Identifying and testing the inhibitors of technology usage intentions. Information Systems Research. doi: 10.1287/isre. 1100.0295 .

Chang, H.H., "An empirical evaluation of performance measurement systems for total quality management", Total Quality Management \& Business Excellence, Vol.17, No.8, 2006, pp.1093-1109.

Chang, H. H., Wang, Y.-H., \& Yang, W.-Y., "The impact of e-service quality, customer satisfaction and loyalty on e-marketing: Moderating effect of perceived value", Total Quality Management \& Business Excellence, Vol.20, No.4, 2009, pp.423-443.

Chen, Y.-Y., Huang, H.-L., Hsu, Y.-C., Tseng, H.-C., \& Lee, Y.-C., "Confirmation of Expectations and Satisfaction with the Internet Shopping: The Role of Internet Self-efficacy", Computer and Information Science, Vol.3, No.3, 2010, pp.14-22.

Davis, F. D., Bagozzi, R. P., \& Warshaw, P. R., 
"Uer acceptance of computer technology: A comparison of two theoretical models", Management Science, Vol.35, No.8, 1989, pp.983-1003.

Diener, E., Smith, H., \& Fujita, F., "The personality structure of affect", Journal of Personality and Social Psychology, Vol.69, No.1, 1995, pp.130-141.

Fornell, C., \& Larcker, D. F., "Evaluating structural equation models with unobservable variables and measurement error", Journal of Marketing Research, Vol. 18, No. 1, 1981, pp. 39-50.

Fraedrich, J. P., \& Ferrell, O. C., "The impact of perceived risk and moral philosophy type on ethical decision making in business organizations", Journal of Business Research, Vol.24, No.4, 1992, pp.283-295.

Gefen, D., "TAM or just plain habit: A look at experienced online shoppers", Journal of End User Computing, Vol.15, No.3, 2003, pp.1-13.

Hair, J. F. Jr., Anderson, R. E., Tatham, R., and Black, W. C., Multivariate Data Analysis, 5th edition, Prentice-Hall, Englewood Cliffs, NJ, 1998.

Herzberg, F., Mausner, B., \& Snyderman, B., "The motivation to work", New York: Wiley, 1959.

Herzberg, F., "One more time: How do you motivate employees?" Harvard Business Review, Vol.65, No.5, 1987, pp.109-120.

Hou, A. C. Y., Chern, C.-C., Chen, H.-G., \&
Chen, Y.-C., " 'Migrating to a new virtual world': Exploring mmorpg switching through human migration theory", Computers in Human Behavior, Vol.27, No.5, 2011, pp.1892-1903.

Hsu, J. S.-C., "Understanding the role of satisfaction in the formation of perceived switching value", Decision Support Systems, Vol.59, March 2014, pp.152-162. Hung, S., Ku, C., \& Chang, C., "Critical factors of WAP services adoption: An empirical study", Electronic Commerce Research and Applications, Vol.2, No.1, 2003, pp.42-60. Kang, Y.-S., Min, J.-Y., Kim, J.-K., Lee, H.-S., "Roles of alternative and self-oriented perspectives in the context of the continued use of social network sites", International Journal of Information Management, Vol.33, No.3, 2013, pp.496-511.

Keil, M., Tan, B. C. Y., Wei, K., Saarinen, T., Tuunainen, V., \& Wassenaar, A., "A cross-cultural study on education of commitment behavior in software projects", MIS Quarterly, Vol.24, 2000, pp.299-325.

Kim, B., "An empirical investigation of mobile data service continuance: Incorporating the theory of planned behavior into the expectation-confirmation model", Expert Systems with Applications, Vol.37, No.10, 2010, pp.7033-7039.

Kim, G., Shin, B., \& Lee, H. G., "A study of factors that affect user intentions toward 
email service switching", Information \& Management, Vol.43, No.7, 2006, pp.884893.

Kim, H.-W. \& Kwahk, K.-Y., "Comparing the usage behavior and the continuance intention of mobile Internet services", Eighth World Congress on the Management of eBusiness, Toronto, Canada, 2007.

Kim, H.W., Chan, H.C., \& Gupta, S., "Value-based adoption of mobile internet: an empirical investigation", Decis. Support. Syst., Vol.43, No.1, 2007, pp.111-126.

Kuo, Y., \& Yen, S., "Towards an understanding of the behavioral intention to use $3 \mathrm{G}$ mobile value-added services", Computers in Human Behavior, Vol.25, No.1, 2009, pp.103-110.

Lee, S., Shin, B., \& Lee, H. G., "Understanding post-adoption usage of mobile data services: The role of supplier-side variables", Journal of the Association for Information Systems, Vol.10, No.12, 2009, pp.860-888.

Lewicki, R. J., McCallister, D. J., \& Bies, R. J., "Trust and distrust: New relationships and realities", Academy of Management Review, Vol.23, No.3, 1998, pp.438-458.

Lian, J.-W., David C. Y., \& Wang, Y.-T., "An exploratory study to understand the critical factors affecting the decision to adopt cloud computing in Taiwan hospital", International Journal of Information Management, Vol.34, No.1, 2014, pp.28-36.

Liao, C., Palvia, P., Lin, H.-N., "The roles of habit and web site quality in e-commerce", International Journal of Information Management, Vol.26, No.6, 2006, pp.469-483.

Liao, C., Lin, H. N., \& Liu, Y. P., "Predicting the use of pirated software: A contingency model integrating perceived risk with the theory of planned behavior", Journal of Business Ethics, Vol.91, No.2, 2010, pp.237-252.

Limayem, M., Hirt, S. G., \& Cheung, C. M. K., "How habit limits the predictive power of intention: The case of information systems continuance", MIS Quarterly, Vol.31, No.4, 2007, pp.705-737.

Lin, G., Fu, D., Zhu, J., \& Dasmalchi, G., "Cloud computing: It as a service", IEEE IT Professional, Vol.12, No.5, 2009, pp.3641.

Lin, T.-C., Wu, S., Hsu, J. S.-C., \& Chou, Y.-C., "The integration of value-based adoption and expectation-confirmation models: An example of IPTV continuance intention", Decision Support Systems, Vol.54, No.1, 2012, pp.63-75.

Lin, C. A., "Exploring personal computer adoption dynamics", Journal of Broadcasting and Electronic Media, Vol.42, No.1, 1998, pp.95-112.

Liu, C.-T., Guo, Y. M., \& Lee, C.-H., "The effects of relationship quality and switching 
barriers on customer loyalty", International Journal of Information Management, Vol.31, No.1, 2011, pp.71-79.

Mariana Carroll, Paula Kotzé \& Alta van der Merwe. 2012. Securing Virtual and Cloud Environments. In: Cloud Computing and Services Science, Service Science: Research and Innovations in the Service Economy), edited by I. Ivanov et al., DOI 10.1007/978-1-4614-2326-3 4, (C) Springer Science+Business Media, LLC 2012.

Marston, S., Li, Z., Bandyopadhyay, S., Zhang, J., \& Ghalsasi, A., "Cloud computing - the business perspective", Decision Support Systems, Vol.51, No.1, 2011, pp.176-189.

Midgley, D. F., \& Dowling, G. R., "Innovativeness: The concept and its measurement", Journal of Consumer Research, Vol.4, No.4, 1978, pp.229-242.

Miller, M., "Cloud computing: Web-based application that change the way you work and collaborate online", QUE Publishing, 2009.

Mossberg, Walter S., "Google Stores, Syncs, Edits in the Cloud". The Wall Street Journal. Retrieved 2012-04-25.

Orbell, S., Blair, C., Sherlock, K., \& Conner, M., "The theory of planned behavior and ecstasy use: Roles for habit and perceived control over taking versus obtaining substances", Journal of Applied Social Psychology, Vol.31, No.1, 2001, pp.31-47.

Ouellette, J. A., \& Wood, W., "Habit and intention in everyday life: The multiple processes by which past behavior predicts future behavior", Psychological Bulletin, Vol.124, No.1, 1998, pp.54-74.

Pallis, G., "Cloud computing: The new frontier of internet computing", IEEE Internet Computing, Vol.14, No.5, 2010, pp.70-73.

Park, S.C., \& Ryoo, S.Y., "An empirical investigation of end-users' switching toward cloud computing: A two factor theory perspective", Computers in Human Behavior, Vol.29, No.1, 2013, pp.160-170.

Pavlou, A. P., "Consumer acceptance of electronic commerce: Integrating trust and risk with the technology acceptance model", International Journal of Electronic Commerce, Vol.7, No.3, 2003, pp.69-103.

Polites, G. L., "Counterintentional habits as an inhibitor of technology acceptance", In Proceedings of the 2005 southern association for information systems conference, 2005.

Polites, G. L., \& Karahanna, E. K., "Shackled to the status quo: the inhibiting effects of incumbent system habit, switching costs, and inertia on new system acceptance", MIS Quarterly, Vol.36, No.1, 2012, pp.21-42.

Prashant Gupta, A. Seetharaman, \& John Rudolph Raj, "The usage and adoption of cloud computing by small and medium businesses", International Journal of Information Management, Vol.33, No.5, 2013, pp.861-874. 
Rayport, J. F., \& Heyward, A. (2009). "Envisioning the cloud: The next computing paradigm and its implication for technology policy".

$<\mathrm{http}$ //www.marketspaceadvisory.com/cl oud/> Accessed May 2011.

Rogers, E. M., \& Shoemaker, F. F., "Communication of innovations", New York: The Free Press, 1971.

Rogers, E.M., "Diffusion of Innovations", Free Press: New York, 1983.

Rogers, E. M., "Diffusion of innovations (4th ed.)", New York: Free Press, 1995.

Stone, R. N., \& Grønhaug, K., "Perceived risk: Further consideration for the marketing discipline", European Journal of Marketing, Vol.27, No.3, 1993, pp.39-50.

Taylor, S., \& Todd, P. A., "Understanding information technology usage: A test of competing models", Information Systems Research, Vol.6, No.2, 1995, pp.144-175.

Vanessa Ratten, "Entrepreneurial and ethical adoption behaviour of cloud computing", The Journal of High Technology Management Research, Vol.23, No.2, 2012, pp.155-164.

Venkatesh, V., Morris, M. G., Davis, G. B., \& Davis, F. D., "User acceptance of information technology: Toward a unified view", Mis Quarterly, Vol.27, No.3, 2003, pp.425-478.

Venkatesh, V., Thong, J. Y. L., \& Xu, X., "CONSUMER ACCEPTANCE AND USE
OF INFORMATION TECHNOLOGY: EXTENDING THE UNIFIED THEORY OF ACCEPTANCE AND USE OF TECHNOLOGY", MIS Quarterly, Vol.36, No.1, 2012, pp.157-178.

Verplanken, B., Aarts, H., and Van Knippenberg, A. "Habit, Information Acquisition, and the Process of Making Travel Mode Choices," European Journal of Social Psychology, Vol.27, No.5, 1997, pp.539-560.

Wang, Y. S., Wang, Y. M., Lin, H. H., \& Tang, T., "Determinants of user acceptance of internet banking: An empirical study", International Journal of Service Industry Management, Vol.14, No.5, 2003, pp.501-519.

Yang, K. C. C., "Exploring factors affecting the adoption of mobile commerce in Singapore", Telematics and Informatics, Vol.22, No.3, 2005, pp.257-277.

Ye, C., Seo, D., Desouza, K., Sangareddy, S. P., \& Jha, S., "Influences of it substitutes and user experience on post adoption user switching: An empirical investigation", Journal of the American Society for Information Science and Technology, Vol.59, No.13, 2008, pp.2115-2132.

Ye, C., \& Potter, R., "The role of habit in post-adoption switching of personal information technologies: A push, pull and mooring model", DIGIT 2007 Proceedings, 2007 , Paper 7. 


\section{라위의(Luo, Weiyi)}

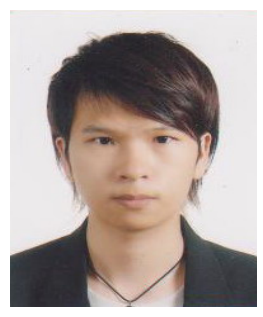

동국대학교 일반대학원 경 영학 석사학위를 취득하고 현 재 동 대학원 국제비즈니스협 동과정 박사과정에 재학 중 이다. Information Systems Review에 논문을 게재하였다. 주요 연구 관심분야는 스마트 폰, 모바일 서비스, 소셜네트워크, 클라우드 컴퓨팅 등 이다.

\section{이영찬(Lee, Young-Chan)}

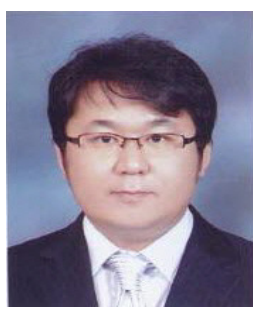

서강대학교 경영학사, 동 대 학원에서 경영학 석사 및 박사 학위를 취득하였다. 현재 동국 대학교 경주캠퍼스 경영학 부 교수로 재직하고 있으며, Annals of Management Science, The Open Operational Research Journal의 Editorial Board, 한국정보시스템 학회 편집위원장으로 활동 중이다. Expert Systems with Applications, Knowledge-Based Systems, Human Factors and Ergonomics in Manufacturing, Technological and Economic Development of Economy, Information Systems Management 등에 논 문을 게재하였으며, 주요 관심 분야는 지식경영, 기업 성과측정, 데이터마이닝, 복잡계 이론, 다기준의사결 정 등이다. 
$<$ Abstract $>$

\title{
What are the Individual's Real Cares to Switch Personal Cloud Services?
}

\author{
Weiyi Luo $\cdot$ Young-Chan Lee
}

As the fast development of information technology (IT), abundant attractive alternatives have showed up and challenged to the traditional information technology (IT). Cloud services, the hottest representative among these alternatives, has attracted the attention from all walks of life. Considering the diversity of cloud services, this study attempts to find out the important factors affected on individual's switching intention from incumbent IT to cloud services mainly based on two-factor theory (switching enablers and switching inhibitors) and explore the direct influences of these factors on individual's switching intention. According to our findings, individual's switching intention to cloud services is not only positively influenced by switching enablers but also negatively influenced by switching inhibitors. All the switching enablers in this study (perceived omnipresence, perceived collaboration support and perceived compatibility of cloud services) have positively significant influences on individual's switching intention as well as the switching inhibitors (usage habit of incumbent IT and perceived risk of cloud services) have negatively significant influences on individual's switching intention. It's noteworthy that satisfaction of incumbent IT has insignificant influence on individual's switching intention in this study. Moreover, as we expected, both social influence and personal innovativeness have significant influences on the generation of individual's switching intention.

Keywords: Personal cloud services, two-factor theory, switching enablers, switching inhibitors, perceived omnipresence of cloud services, perceived collaboration support of cloud services, perceived compatibility of cloud services, satisfaction of incumbent IT, usage habit of incumbent IT, perceived risk of cloud services, social influence, personal innovativeness, intention to switch

* 이 논문은 2014년 5월 2일 접수하여 1차 수정을 거쳐 2014년 6월 25일 게재 확정되었습니다. 